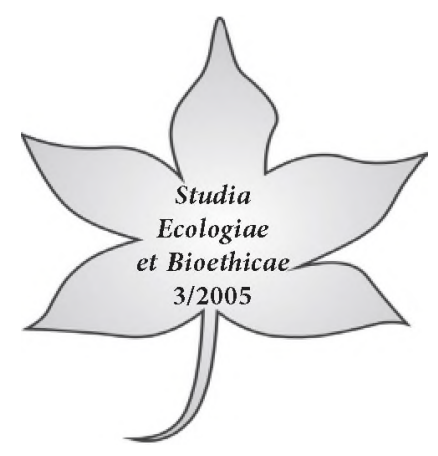

\title{
Epistemologiczne i metodologiczne aspekty sozologii
}

\section{Wprowadzenie}

Koniecznym wydaje się zapoznanie środowiska policyjnego z nauką, zajmującą się całościowo ochroną środowiska przyrodniczego, jaką jest sozologia. W prowadzonych przeze mnie badaniach naukowych wśród policjantów, gdzie za pomocą ankiety o tematyce: wiadomości i świadomość ekologiczna policjantów, przebadałem 500 funkcjonariuszy Policji - tylko $2 \%$ spośród ankietowanych skojarzyło ją z ochroną przyrody, podczas gdy $98 \% \mathrm{z}$ ochroną środowiska mylnie wiązało wyłącznie ekologię. Taka sytuacja, wręcz zmusza do możliwie szerokiego zdefiniowania sozologii oraz przedstawienia, chociaż pokrótce, jej aspektów epistemologicznych i metodologicznych, a ponadto wymaga szerszego włączenia jej do policyjnych programów nauczania. Przecież policjant prowadzący postępowania przygotowawcze dotyczące przestępstw i wykroczeń przeciwko środowisku przyrodniczemu powinien wiedzieć, jaka nauka zajmuje się ochroną środowiska.

\section{Epistemologiczne aspekty sozologii}

Nazwę tę, używaną w Polsce jako określenie nauki o nowocześnie pojętej ochronie środowiska, wprowadził w 1965 roku Walery Goetel geolog, profesor Akademii Górniczo-Hutniczej w Krakowie. Wyraz „sozologia” pochodzi z języka greckiego i składa się z dwóch wyrazów: sozo, co znaczy chronię, ratuję, pomagam i logos - nauka ${ }^{1}$. Wydawać się może, że jest to młoda dyscyplina, lecz wrażenie to jest zgoła złudne.

Początki ochrony przyrody, jako środowiska życia człowieka, można odnaleźć już w najdawniejszych źródłach związanych np. z wierzeniami religijnymi. Pierwotne motywy ochrony przyrody dotyczyły małego zakresu obiektów przy-

Z. Wójcik, By ziemia pozostała piękna i zasobna, WSiP, Warszawa 1996, s. 20. 
rodniczych, ale nawet one, wprawdzie częściowo, lecz dość skutecznie zabezpieczały przyrodę przed gospodarczą działalnością człowieka.

Termin „sozologia” uwzględnia dwa aspekty - treściowy i zakresowy. Pierwszy wskazuje na elementy metodologiczne i przedmiotowe tej nazwy, natomiast drugi wyznacza jej zakres ${ }^{2}$. Aspekt przedmiotowy określa zagadnienia i problemy wchodzące w zakres naukowych badań sozologicznych. Można tu mówić o takich problemach i zagadnieniach, jak:

- opis faktyczny stanu przyrody w Polsce i na świecie,

- określenie obiektów, które zanieczyszczają i niszczą środowisko,

- prowadzenie badań technicznych i technologicznych w celu upowszechniania stosowania urządzeń oczyszczających i technologii nieuciążliwych dla środowiska,

- badanie zmiennego wpływu środowiska na organizmy żywe i na człowieka,

- tworzenie zabezpieczeń prawnych i administracyjnych w skali krajowej i międzynarodowej służących realizacji programów ochrony środowiska,

- budzenie świadomości moralnej i etycznej wrażliwej na jakość środowiska przyrodniczego i społecznego,

- poszukiwanie sposobów i środków zmniejszenia zanieczyszczania środowiska i eliminowanie źródeł takich zanieczyszczeń,

- badanie wpływu środowiska na stan psychiczny człowieka,

- prowadzenie badań medycznych nad nowymi jednostkami chorobowymi powstającymi pod wpływem zmieniającego się środowiska,

- zabezpieczenie tzw. czystych rezerw genetycznych,

- wychowanie, na różnych szczeblach edukacji narodowej, w duchu wrażliwości na wartości naturalnego środowiska człowieka ${ }^{3}$.

Aspekt zakresowy sozologii obejmuje problemy i zagadnienia dotyczące środowiska przyrodniczego i społecznego, w którym żyje człowiek. Obejmuje on wszystkie obszary przyrody ożywionej i nieożywionej, ich wpływ na życie i zdrowie człowieka. Mieszczą się tu badania naturalnych właściwości obiektów przyrody, a także zmian, powstałych w przyrodzie pod wpływem działalności człowieka ${ }^{4}$.

Sozologia jako nauka zajmująca się problematyką ochrony przyrody nie jest do końca precyzyjnie zdefiniowana. I tak np. Włodzimierz Michajłow podaje dwie definicje:

2 J.M. Dołęga, Problematyka ochrony środowiska społeczno - przyrodniczego w sozologii i ekofilozofii, (w:) Ochrona środowiska w filozofii i teologii, pod red. J. M. Dolęgi i J. W. Czartoszewskiego, Wydawnictwo ATK, Warszawa 1999, s. 11.

3 J.M. Dołęga, Problematyka ochrony środowiska społeczno - przyrodniczego w sozologii i ekofilozofii, (w:) Ochrona środowiska w filozofii i teologii, pod red. J. M. Dołęgi i J. W. Czartoszewskiego, Wydawnictwo ATK, Warszawa 1999, s. 12-13.

4 Tamże, s. 13. 
I. „sozologia, nauka o ochronie przyrody, zajmuje się przyczynami i doraźnymi skutkami oraz dalszymi nastepstwami przemian zachodzacych w wyniku działalności gospodarczej i społecznej człowieka zarówno w naturalnych, jak i uprzednio odkształconych układach przyrodniczych, na mniejszym lub większym obszarze biosfery. Zakresem swym obejmuje skuteczne sposoby zapobiegania ujemnym dla społeczeństw następstwom działalności człowieka w środowisku naturalnym, bądź przynajmniej wskazuje możliwości maksymalnego ich złagodzenia."

II. „sozologia jest naukq o przyczynach i doraźnych skutkach, a także dalszych nastepstwach przemian zachodzacych zarówno w naturalnych, jak $i$ uprzednio juz odkształconych układach przyrodniczych, na mniejszym lub większym obszarze biosfery, w wyniku dzialalności spolecznej i gospodarczej czlowieka oraz o skutecznych sposobach zapobiegania jej ujemnym następstwom dla społeczeństw lub przynajmniej o możliwościach maksymalnego ich złagodzenia"s.

Natomiast prof. Józef. M. Dołęga definiuje sozologię w następujący sposób: „sozologia jest nauka o systemowej ochronie biosfery przed destrukcyjnym oddzialywaniem antroposfery".

$\mathrm{Na}$ własny użytek przyjąłem definicję stanowiącą połączenie elementów pojęć, zawartych w literaturze przedmiotu, która określa, że: „sozologia to nauka zajmująca się w sposób kompleksowy i systemowy ochrona środowiska naturalnego przed niszczącq działalnościq człowieka".

Sozologia zajmuje się podstawami ochrony przyrody i jej zasobów oraz zapewnieniem trwałości ich użytkowania. Bada przyczyny oraz następstwa przemian w naturalnych lub odkształconych układach przyrodniczych (na mniejszych lub większych obszarach) zachodzących w wyniku działalności człowieka. Wypracowuje skuteczne sposoby zapobiegania ujemnym skutkom tych zmian dla społeczeństwa lub co najmniej możliwości maksymalnego ich łagodzenia ${ }^{7}$. Jako kompleksowa nauka przyrodnicza współpracuje z ekologią, geologią, ekonomią, dyscyplinami technicznymi, a także z etyką i pedagogiką, a nawet z kryminalistyką. Ze współpracy tej rodzą się nowe dziedziny naukowe, takie jak: sozotechnika, sozoekologia, sozopsychologia, sozoetyka, etyka ekologiczna, prawo ekologiczne czy sozologiczne ${ }^{8}$.

5 Tamże, s. 13 -15; W. Michajłow, Sozologia i problemy środowiska życia człowieka, Warszawa 1975 , s. 50.

6 J.M. Dołęga, Problematyka ochrony środowiska społeczno - przyrodniczego w sozologii i ekofilozofii, (w:) Ochrona środowiska w filozofii i teologii, pod red. J. M. Dolegi i J. W. Czartoszewskiego, Wydawnictwo ATK, Warszawa 1999, s. 14.

7 J. M. Dołęga, Koncepcja sozologii systemowej, Wydawnictwo UKSW, Warszawa 2001, s. 11-19.

8 J. M. Dołęga, Człowiek w zagrożonym środowisku, Wydawnictwo ATK, Warszawa 1998, s. 41-42. 
Pod kierunkiem wybitnego znawcy przedmiotu - prof. Józefa Marcelego Dołęgi chcę podjąć próbę zdefiniowania i wprowadzenia do wykazu nauk sozokryminalistykę, jako nową naukę, z określeniem jej aspektów epistemologicznych i metodologicznych. Miałaby ona za zadanie wypracowanie metod i środków koniecznych do zwalczania przestępczości przeciwko środowisku oraz zapobiegania jej.

Obecnie sozologia rozwija się także w innych krajach, w których nadaje się jej różne nazwy.

\section{Metodologiczne aspekty sozologii}

Zakres badań sozologii obejmuje przyrodę ożywioną i nieożywioną, przez co należy rozumieć szeroko pojęte środowisko życia człowieka ulegające różnorakim zmianom, a czasami całkowitej destrukcji, właśnie pod wpływem oddziaływania antroposfery.

Sozologia w swoich badaniach uwzględnia również struktury genetyczne roślin i zwierząt, ich prawidłowy rozwój, a także zakłócenia spowodowane oddziaływaniem antroposfery. Ponadto obejmuje środowisko fizyczne jako szeroko pojętą biosferę, a więc atmosferę, hydrosferę, litosferę i kosmosferę. Oprócz ogólnego, wskazanego przedmiotu badań sozologii, zajmuje się ona obecnym stanem życia środowiska, źródłami jego zanieczyszczeń, ich wpływem na życie, zdrowie człowieka i innych organizmów żywych, jak też sposobami ochrony tego środowiska.

Ogólnie można stwierdzić, iż przedmiotem badań sozologii jest wpływ działalności człowieka na przyrodę oraz metody i sposoby jej ochrony ${ }^{9}$. Naukowe badania sozologiczne charakteryzuje interdyscyplinarność i systemowość, rozwiązuje ona wszechstronnie i wyczerpująco pojawiające się problemy.

W aspekcie metodologicznym zawarte są metody służące badaniu przedmiotu sozologii. Wyróżnia się następujące grupy metod: empiryczne, humanistyczne, filozoficzne i systemowe ${ }^{10}$.

Podstawową metodą, stosowaną w naukach empirycznych, jak również w sozologii, jest obserwacja naukowa, która może być bezpośrednia lub pośrednia, a także ilościowa albo jakościowa, niekiedy poparta analizami laboratoryjnymi, pomiarami, a następnie opisana ${ }^{11}$.

9 J.M. Dołęga, Problematyka ochrony środowiska społeczno - przyrodniczego w sozologii i ekofilozofii, (w:) Ochrona środowiska w filozofii i teologii, pod red. J. M. Dołęgi i J. W. Czartoszewskiego, Wydawnictwo ATK, Warszawa 1999, s. 15-17.

10 Tamże, s. 18.

11 J. M. Dołęga, Koncepcja sozologii systemowej, WUKSW, Warszawa 2001, s. 45-51. 
Sozologia musi uwzględniać również niektóre nauki humanistyczne i przyrodniczo-humanistyczne, w obszarze których znajduje się człowiek, jego stan biologiczny i psychiczny, działalność gospodarczą i kulturową w zagrożonym środowisku oraz aspekty etyczno-moralne tej działalności ${ }^{12}$.

W metodologii filozofii ważne jest wypracowanie stosownych metod dla poszczególnych dyscyplin filozoficznych. Trzeba tu przede wszystkim wskazać na analizę filozoficzną, w ramach której wyróżnia się dwa typy: ontologiczną (w znaczeniu ścisłym) stosowaną w filozofii bytu oraz analizę skierowaną na taki rodzaj bytu, który występuje w przyrodzie (czyli na materialny) ${ }^{13}$.

Metoda systemowa jest szczególnie preferowana w sozologii ${ }^{14}$. W badaniach naukowych z zakresu sozologii wymagane jest podejście systemowe, zarówno w aspekcie przedmiotowym, jak i metodologicznym. Wykorzystuje się przy tym wiele metod i technik w celu rozpoznania aktualnego stanu środowiska oraz ukazuje konieczność zastosowania środków mających zahamować degradację tego środowiska. Zbiór tych metod i technik stanowi pewien system moźliwości badawczych sozologii15.

\title{
Bibliografia
}

DoŁęGA J. M., Człowiek w zagrożonym środowisku, Wydawnictwo ATK, Warszawa 1998.

DoŁĘGA J. M., Koncepcja sozologii systemowej, WUKSW, Warszawa 2001.

MichajŁow W., Sozologia i problemy środowiska życia człowieka, Warszawa 1975.

Wójcık Z., By ziemia pozostała piękna i zasobna, WSiP, Warszawa 1996.

Ochrona środowiska w filozofii i teologii, red. J. M. Dołęga i J. W. Czartoszewsk, Wydawnictwo

ATK, Warszawa 1999.

\section{Episthemological and methodological aspects of sozology}

\begin{abstract}
It seems necessary that the police surroundings should get known about the natural environmental protection which sozology is. During the research that I carried out among the policemen I've done the questionnare about information and ecological consciousness of the police. I've examined 500 policemen. Just $2 \%$ of the surveyed brought the environmental protection to their mind, $98 \%$ wrongly thought just about ecology. This situation forces wider defining teh sozology and presenting its episthemological and methodological aspects. What is more it demands wider participation in police teaching programmes.
\end{abstract}

12 Tamże, s. 51-52.

Tamże, s. 53-54.

14 Tamże, s. 43-45.

15 Tamże, s. 55-56. 